\title{
A Quantum Chemistry Approach to the Force Fields of the Asymmetrical Thionyl Halides $\mathrm{FS}(\mathrm{O}) \mathrm{Cl}, \mathrm{CF}_{3} \mathrm{~S}(\mathrm{O}) \mathrm{F}$ and $\mathrm{CF}_{3} \mathrm{~S}(\mathrm{O}) \mathrm{Cl}$
}

\author{
Angelina del C. Coronel ${ }^{\mathrm{a}}$, Myriam E. Gargiulo ${ }^{\mathrm{b}}$, Eduardo L. Varetti ${ }^{\mathrm{c}}$, and Lis E. Fernández ${ }^{\mathrm{d}}$ \\ a Instituto de Química Orgánica, Facultad de Bioquímica, Química y Farmacia, UNT, Ayacucho 471, \\ 4000 S. M. de Tucumán, R. Argentina \\ b Instituto de Matemáticas, Facultad de Bioquímica, Química y Farmacia, UNT, Ayacucho 471, \\ 4000 S. M. de Tucumán, R. Argentina \\ c Centro de Química Inorgánica (CEQUINOR, CONICET-UNLP), Departamento de Química, \\ Facultad de Ciencias Exactas, Universidad Nacional de La Plata, C. Correo 962, 1900 La Plata, \\ R. Argentina \\ d Instituto de Química Física, Facultad de Bioquímica, Química y Farmacia, \\ Universidad Nacional de Tucumán, San Lorenzo 456, 4000 S. M. de Tucumán, R. Argentina \\ Reprint requests to Dra. Lis E. Fernández. E-mail: soler@ fbqf.unt.edu.ar
}

Z. Naturforsch. 2011, 66b, 499-504; received December 28, 2010; in revised form February 18, 2011

\begin{abstract}
The vibrational properties of the asymmetrical thionyl halides $\mathrm{FS}(\mathrm{O}) \mathrm{Cl}_{1} \mathrm{CF}_{3} \mathrm{~S}(\mathrm{O}) \mathrm{F}$ and $\mathrm{CF}_{3} \mathrm{~S}(\mathrm{O}) \mathrm{Cl}$ were studied by means of density functional theory (DFT) techniques. The available experimental data and assignments for these molecules were compared with the theoretical results and revised. These data were subsequently used in the definition of the corresponding scaled quantum mechanics (SQM) force fields. A set of internal force constants was also calculated from such force fields.
\end{abstract}

Key words: Thionyl Halides, Force Constants, Structure, DFT Calculations

\section{Introduction}

Systematic theoretical studies on the vibrational properties of structurally related halides have been performed in this laboratory in the last years in order to revise the assignment of published frequencies and to calculate consistent sets of force constants. In this work we have studied the symmetric sulfuryl halides $\mathrm{SO}_{2} X_{2}(X=\mathrm{F}, \mathrm{Cl}, \mathrm{Br})[1]$, the mixed sulfuryl halides $\mathrm{SO}_{2} X \mathrm{~F}(X=\mathrm{Cl}, \mathrm{Br})$ [2], the molecule $\mathrm{CF}_{3} \mathrm{SO}_{2} \mathrm{Cl}$ [3], the molecule $\mathrm{CF}_{3} \mathrm{SO}_{2} \mathrm{~F}$ as a member of the isoelectronic series $\mathrm{CF}_{3} \mathrm{SO}_{2} \mathrm{X}\left(\mathrm{X}=\mathrm{F}, \mathrm{OH}, \mathrm{NH}_{2}, \mathrm{CH}_{3}\right)$ [4], and the thionyl and selenyl halides $\mathrm{SO}_{2}$ and $\mathrm{SeO} X_{2}$ $(X=\mathrm{F}, \mathrm{Cl}, \mathrm{Br})$ [5]. Now, we turn our attention to the asymmetrical thionyl halides $\mathrm{FS}(\mathrm{O}) \mathrm{Cl}, \mathrm{CF}_{3} \mathrm{~S}(\mathrm{O}) \mathrm{F}$ and $\mathrm{CF}_{3} \mathrm{~S}(\mathrm{O}) \mathrm{Cl}$.

The gas-phase structure of the $\mathrm{CF}_{3} \mathrm{~S}(\mathrm{O}) \mathrm{F}$ molecule has been determined by electron diffraction by Minkwitz et al. [6]. No experimental structural data for $\mathrm{FS}(\mathrm{O}) \mathrm{Cl}$ and $\mathrm{CF}_{3} \mathrm{~S}(\mathrm{O}) \mathrm{Cl}$ were found in the literature. The gas-phase infrared and liquid-phase Raman spectra and assignments for the three thionyl halides have been reported by Kirchmeier and Shreeve [7]. The vibrational frequencies for $\mathrm{CF}_{3} \mathrm{~S}(\mathrm{O}) \mathrm{F}$, isolated in an argon matrix, have been published by Bielefeldt $e t$ al. [8]. A theoretical calculation of geometrical parameters and vibrational frequencies for $\mathrm{FS}(\mathrm{O}) \mathrm{Cl}$ has also been performed as part of a study on its enthalpy of formation [9]. In the present work, the assignment of the published vibrational data was revised and used for the definition of a scaled quantum mechanical (SQM) force field for each molecule.

\section{Calculations}

In order to predict the structural and vibrational properties of the title thionyl halides, exploratory calculations were performed at different levels of theory and with different basis sets: at the Hartree-Fock level using the 6-31G(d) basis set, and with density functional theory (DFT) methods by means of the B3LYP $[10,11]$ and B3PW91 $[10,12]$ functionals and using the $6-31 \mathrm{G}$ and $6-311 \mathrm{G}$ basis sets alone or augmented with diffuse and/or polarized functions. In addition, MP2 [13] methods and the use of the cc-pVTZ [14] basis sets were also assessed in terms of their suitability. The calculations were made in all cases for the isolated molecules using the GaUsSIAN 03 set of programs [15]. The results of these calculations are available from the authors. 
Inspection of the structural calculations for $\mathrm{CF}_{3} \mathrm{~S}(\mathrm{O}) \mathrm{F}$, the only molecule (of the three studied) for which an experimental structure is known, has revealed that the MP2 and B3LYP methods along with the same basis set $(6-311 \mathrm{G}+(3 \mathrm{df})$ or cc-pVTZ) yield comparable results and agree very well with the experiment. The MP2/6-311+G(3df) calculation gives the lowest average bond length errors $(0.018 \AA)$.

In the calculated spectra of $\mathrm{CF}_{3} \mathrm{~S}(\mathrm{O}) \mathrm{F}$ and $\mathrm{CF}_{3} \mathrm{~S}(\mathrm{O}) \mathrm{Cl}$, significant variations were observed in the region of the stretching modes of the $\mathrm{S}=\mathrm{O}$ and $\mathrm{CF}_{3}$ groups depending on the employed basis set. The relative location of the frequencies corresponding to these modes were reproduced satisfactorily using the B3LYP/6-311G+(3df) combination. This level of calculation was therefore adopted for all three molecules.

The harmonic force constants in Cartesian coordinates given by the theoretical calculations were transformed to natural (local symmetry) coordinates as defined by Fogarasi et al. [16] through the corresponding B matrix [17], calculated with a standard program. Such force fields were subsequently scaled using the scheme of Pulay et al. [18], in which the diagonal force constants are multiplied by scale factors $f_{\mathrm{i}}, f_{\mathrm{j}}$, etc., and the corresponding interaction constants are multiplied by $\left(f_{\mathrm{i}} \cdot f_{\mathrm{j}}\right)^{1 / 2}$, adjusting these factors by a least-squares procedure to reproduce the experimental frequencies as well as possible. No anharmonicity corrections of these frequencies were undertaken because of the lack of the necessary experimental data. The potential energy distribution (PED), which gives the participation of each defined coordinate to each normal mode of vibration, was calculated with the resulting scaled quantum mechanical (SQM) force fields.

The force field transformation, scaling and PED calculation were performed with the program FCARTP [19]. The calculated atomic displacement vectors given by the GAUSSIAN 03 programs for each vibrational mode were visualized by means of the MOLDRAW program [20] and served to understand qualitatively the nature of the molecular vibrations.

Atomic charges and Wiberg bond indexes [21] for the studied molecules were calculated by means of the natural bond orbitals (NBO) approach [22], as implemented in the GAUSSIAN 03 package, using also the B3LYP/6-311G+(3df) combination.

\section{Structural Results}

The geometry optimization procedures predicted in all cases the expected pyramidal structures of $C_{1}$ sym-
Table 1. Optimized geometric parameters for the molecules $\mathrm{FS}(\mathrm{O}) \mathrm{Cl}, \mathrm{CF}_{3} \mathrm{~S}(\mathrm{O}) \mathrm{F}$ and $\mathrm{CF}_{3} \mathrm{~S}(\mathrm{O}) \mathrm{Cl}$ and experimental values for $\mathrm{CF}_{3} \mathrm{~S}(\mathrm{O}) \mathrm{F}$.

\begin{tabular}{|c|c|c|c|c|}
\hline & \multirow{2}{*}{$\begin{array}{l}\mathrm{FS}(\mathrm{O}) \mathrm{Cl} \\
\text { calcd. }^{\mathrm{a}}\end{array}$} & \multicolumn{2}{|c|}{$\mathrm{CF}_{3} \mathrm{~S}(\mathrm{O}) \mathrm{F}$} & \multirow{2}{*}{$\begin{array}{c}\mathrm{CF}_{3} \mathrm{~S}(\mathrm{O}) \mathrm{C} \\
\text { calcd. }^{\mathrm{a}}\end{array}$} \\
\hline & & calcd. ${ }^{\mathrm{a}}$ & exp. [6] & \\
\hline \multicolumn{5}{|l|}{$\overline{\text { Bonds, } \bar{A}}$} \\
\hline $\mathrm{S}=\mathrm{O}$ & 1.429 & 1.443 & $1.422(5)$ & 1.453 \\
\hline S-F & 1.617 & 1.627 & 1.591(4) & - \\
\hline $\mathrm{S}-\mathrm{Cl}$ & 2.107 & - & - & 2.107 \\
\hline $\mathrm{S}-\mathrm{C}$ & - & 1.910 & $1.889(5)$ & 1.919 \\
\hline $\mathrm{C}-\mathrm{F}^{\mathrm{b}}$ & - & 1.328 & $1.322(3)$ & 1.329 \\
\hline \multicolumn{5}{|l|}{ Angles, deg } \\
\hline $\mathrm{O}=\mathrm{S}-\mathrm{F}$ & 106.4 & 108.4 & $103.9(11)^{\mathrm{c}}$ & - \\
\hline $\mathrm{O}=\mathrm{S}-\mathrm{Cl}$ & 108.0 & - & - & 110.1 \\
\hline $\mathrm{F}-\mathrm{S}-\mathrm{Cl}$ & 95.1 & - & - & - \\
\hline $\mathrm{O}=\mathrm{S}-\mathrm{C}$ & - & 105.1 & $103.6(35)^{\mathrm{c}}$ & 104.6 \\
\hline $\mathrm{C}-\mathrm{S}-\mathrm{F}$ & - & 90.9 & $93.7(26)$ & - \\
\hline $\mathrm{C}-\mathrm{S}-\mathrm{Cl}$ & - & - & - & 93.9 \\
\hline $\mathrm{F}-\mathrm{C}-\mathrm{F}^{\mathrm{b}}$ & - & 109.6 & 109.9(3) & 109.5 \\
\hline $\mathrm{F}-\mathrm{C}-\mathrm{S}^{\mathrm{b}}$ & - & 109.3 & - & 109.3 \\
\hline $\mathrm{F}-\mathrm{C}-\mathrm{S}-\mathrm{F}(\mathrm{Cl})$ & - & 59.1 & $40(7)$ & 61.2 \\
\hline $\mathrm{O}=\mathrm{S}-\mathrm{C}-\mathrm{F}$ & - & -50.3 & $-60(7)$ & -50.7 \\
\hline
\end{tabular}

${ }^{\mathrm{a}} \mathrm{B} 3 \mathrm{LYP} / 6-311+\mathrm{G}(3 \mathrm{df})$ calculations; ${ }^{\mathrm{b}}$ mean values; ${ }^{\mathrm{c}}$ these angles are not well determined in this study but correspond within experimental uncertainties to those of $\mathrm{F}_{2} \mathrm{SO}$ and $\left(\mathrm{CF}_{3}\right)_{2} \mathrm{SO}$.
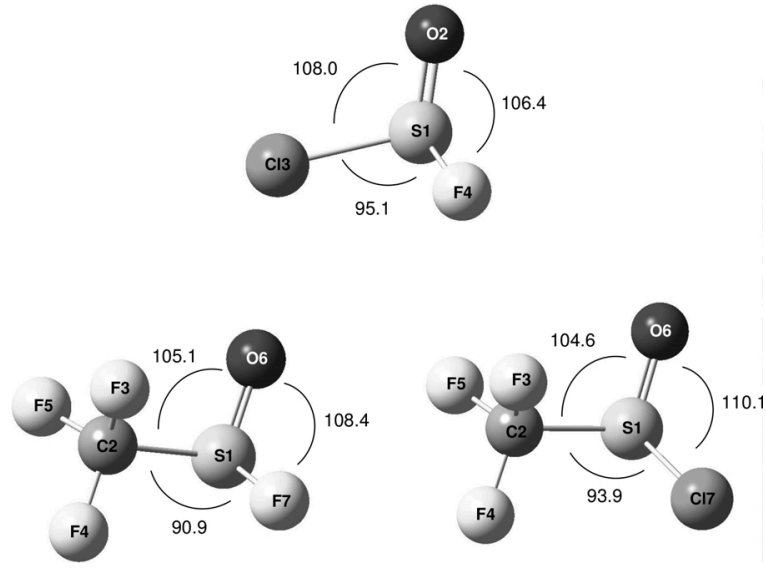

Fig. 1. Optimized molecular structures and some calculated angles for the molecules $\mathrm{FS}(\mathrm{O}) \mathrm{Cl}, \mathrm{CF}_{3} \mathrm{~S}(\mathrm{O}) \mathrm{F}$ and $\mathrm{CF}_{3} \mathrm{~S}(\mathrm{O}) \mathrm{Cl}$.

metry depicted in Fig. 1 along with some calculated angles that will be discussed below. The optimized geometrical parameters are collected in Table 1, together with the available experimental data for $\mathrm{CF}_{3} \mathrm{~S}(\mathrm{O}) \mathrm{F}$ obtained from electron diffraction measurements.

The most stable conformations predicted by the calculations for $\mathrm{CF}_{3} \mathrm{~S}(\mathrm{O}) \mathrm{F}$ and $\mathrm{CF}_{3} \mathrm{~S}(\mathrm{O}) \mathrm{Cl}$ show that the $\mathrm{CF}_{3}$ groups adopt staggered orientations relative to the $\mathrm{S}=\mathrm{O}$ and $\mathrm{S}-\mathrm{F}(\mathrm{Cl})$ bonds. The eclipsed conformations turned out to be transition states characterized by imaginary frequencies for the $\mathrm{CF}_{3}$ torsions. 
Table 2. Experimental and calculated frequencies $\left(\mathrm{cm}^{-1}\right)$, infrared and Raman intensities and potential energy distributions for $\mathrm{FS}(\mathrm{O}) \mathrm{Cl}$.

\begin{tabular}{|c|c|c|c|c|c|c|c|}
\hline Mode & exp. [7] & calcd. $^{\mathrm{a}}$ & calcd. SQM ${ }^{\mathrm{b}}$ & IR int. ${ }^{\mathrm{c}}$ & Raman int. $^{d}$ & $\mathrm{PED}^{\mathrm{e}}$ & Main coordinate \\
\hline$\overline{v_{1}}$ & 1293 vs & 1305 & 1293 & 171.6 & 19.3 & $100 \mathrm{~S}_{1}$ & $v(\mathrm{~S}=\mathrm{O})$ \\
\hline$v_{2}$ & 751 vs & 720 & 745 & 159.6 & 6.6 & $89 \mathrm{~S}_{2}$ & $v(\mathrm{~S}-\mathrm{F})$ \\
\hline$v_{3}$ & $514 \mathrm{~s}$ & 490 & 542 & 125.0 & 6.1 & $31 \mathrm{~S}_{3}+39 \mathrm{~S}_{5}+11 \mathrm{~S}_{6}$ & $v(\mathrm{~S}-\mathrm{Cl})$ \\
\hline$v_{4}$ & $435 \mathrm{w}$ & 430 & 442 & 40.7 & 7.2 & $84 \mathrm{~S}_{4}+20 \mathrm{~S}_{3}$ & $\delta(\mathrm{O}=\mathrm{S}-\mathrm{F})$ \\
\hline$v_{5}$ & $347^{*} \mathrm{~s}$ & 298 & 326 & 5.0 & 10.3 & $50 \mathrm{~S}_{5}+45 \mathrm{~S}_{3}+13 \mathrm{~S}_{4}$ & $\delta(\mathrm{O}=\mathrm{S}-\mathrm{Cl})$ \\
\hline$v_{6}$ & $314^{*}$ vs & 251 & 291 & 0.4 & 2.4 & $94 \mathrm{~S}_{6}+20 \mathrm{~S}_{5}$ & $\delta(\mathrm{F}-\mathrm{S}-\mathrm{Cl})$ \\
\hline \multicolumn{2}{|c|}{ RMSD, $\mathrm{cm}^{-1}$} & 37 & 17 & & & & \\
\hline
\end{tabular}

Table 3. Experimental and calculated frequencies $\left(\mathrm{cm}^{-1}\right)$, infrared and Raman intensities and potential energy distributions for $\mathrm{CF}_{3} \mathrm{~S}(\mathrm{O}) \mathrm{F}$.

\begin{tabular}{|c|c|c|c|c|c|c|c|}
\hline Mode & exp. [7] & calcd. $^{\mathrm{a}}$ & calcd. SQM ${ }^{\mathrm{b}}$ & IR int. $^{\mathrm{c}}$ & Raman int. $^{d}$ & $\mathrm{PED}^{\mathrm{e}}$ & Main coordinate \\
\hline$\overline{v_{1}}$ & $1267 \mathrm{vs}$ & 1271 & 1267 & 186.1 & 14.4 & $76 \mathrm{~S}_{1}+10 \mathrm{~S}_{2}$ & $v(\mathrm{~S}=\mathrm{O})$ \\
\hline$v_{2}$ & 1226 vs & 1221 & 1237 & 217.9 & 2.5 & $82 S_{2}+14 S_{1}+17 S_{7}$ & $v\left(\mathrm{CF}_{3}\right.$ antisym. $)$ \\
\hline$v_{3}$ & 1213 vs & 1186 & 1204 & 215.8 & 2.1 & $95 \mathrm{~S}_{3}+18 \mathrm{~S}_{8}$ & $v\left(\mathrm{CF}_{3}\right.$ antisym. $)$ \\
\hline$v_{4}$ & 1152 vs & 1126 & 1146 & 269.5 & 9.4 & $59 S_{4}+39 S_{5}+17 S_{12}$ & $v\left(\mathrm{CF}_{3}\right.$ sym. $)$ \\
\hline$v_{5}$ & 757 vs & 749 & 764 & 2.2 & 9.2 & $35 \mathrm{~S}_{5}+37 \mathrm{~S}_{4}+14 \mathrm{~S}_{12}$ & $\delta\left(\mathrm{CF}_{3}\right.$ sym. $)$ \\
\hline$v_{6}$ & $749 \mathrm{~s}$ & 720 & 749 & 131.4 & 6.6 & $94 \mathrm{~S}_{6}$ & $v(\mathrm{~S}-\mathrm{F})$ \\
\hline$v_{7}$ & $590 \mathrm{~m}$ & 579 & 592 & 27.4 & 2.2 & $24 \mathrm{~S}_{7}+20 \mathrm{~S}_{9}$ & $\delta\left(\mathrm{CF}_{3}\right.$ antisym. $)$ \\
\hline$v_{8}$ & $555 \mathrm{vw}$ & 540 & 550 & 1.5 & 1.2 & $62 \mathrm{~S}_{8}$ & $\delta\left(\mathrm{CF}_{3}\right.$ antisym. $)$ \\
\hline$v_{9}$ & $480 \mathrm{~m}$ & 473 & 482 & 26.7 & 1.2 & $17 \mathrm{~S}_{9}+56 \mathrm{~S}_{7}$ & wag. $(\mathrm{O}=\mathrm{S}-\mathrm{F})$ \\
\hline$v_{10}$ & $409^{*} \mathrm{~m}$ & 401 & 411 & 16.5 & 4.4 & $69 \mathrm{~S}_{10}+20 \mathrm{~S}_{12}$ & $\delta(\mathrm{O}=\mathrm{S}-\mathrm{F})$ \\
\hline$v_{11}$ & $342^{*} \mathrm{~m}$ & 332 & 351 & 1.0 & 2.3 & $36 \mathrm{~S}_{11}+29 \mathrm{~S}_{14}+22 \mathrm{~S}_{8}$ & $\rho\left(\mathrm{CF}_{3}\right)$ \\
\hline$v_{12}$ & $289^{*}$ vs & 275 & 288 & 1.0 & 4.5 & $32 \mathrm{~S}_{12}+32 \mathrm{~S}_{13}+21 \mathrm{~S}_{10}$ & $v(\mathrm{C}-\mathrm{S})$ \\
\hline$v_{13}$ & $220^{*} \mathrm{~m}$ & 203 & 212 & 3.3 & 0.9 & $70 S_{13}+59 S_{9}$ & $\rho\left(\mathrm{CF}_{3}\right)$ \\
\hline$v_{14}$ & $192^{*} \mathrm{w}$ & 173 & 184 & 1.9 & 0.2 & $68 \mathrm{~S}_{14}+66 \mathrm{~S}_{11}$ & twist. $(\mathrm{O}=\mathrm{S}-\mathrm{F})$ \\
\hline$v_{15}$ & - & 55 & 55 & 0.8 & 0.2 & $108 \mathrm{~S}_{15}$ & torsion $\left(\mathrm{CF}_{3}\right)$ \\
\hline \multicolumn{2}{|c|}{ RMSD, $\mathrm{cm}^{-1}$} & 16 & 6 & & & & \\
\hline
\end{tabular}

Table 4. Experimental and calculated frequencies $\left(\mathrm{cm}^{-1}\right)$, infrared and Raman intensities and potential energy distributions for $\mathrm{CF}_{3} \mathrm{~S}(\mathrm{O}) \mathrm{Cl}$ molecule.

\begin{tabular}{|c|c|c|c|c|c|c|c|}
\hline Mode & exp. [7] & calcd. $^{\mathrm{a}}$ & calcd. SQM ${ }^{b}$ & IR int. ${ }^{\mathrm{c}}$ & Raman int. $^{\mathrm{d}}$ & $\mathrm{PED}^{\mathrm{e}}$ & Main coordinate \\
\hline$\overline{v_{1}}$ & $1242 \mathrm{~s}$ & 1235 & 1244 & 280.4 & 8.0 & $92 \mathrm{~S}_{1}$ & $v(\mathrm{~S}=\mathrm{O})$ \\
\hline$v_{2}$ & $1218 \mathrm{~s}$ & 1215 & 1193 & 164.8 & 9.9 & $87 \mathrm{~S}_{2}+18 \mathrm{~S}_{7}$ & $v\left(\mathrm{CF}_{3}\right)$ antisym. \\
\hline$v_{3}$ & $1123 \mathrm{~s}$ & 1181 & 1151 & 121.0 & 3.7 & $90 \mathrm{~S}_{3}+20 \mathrm{~S}_{8}$ & $v\left(\mathrm{CF}_{3}\right)$ antisym. \\
\hline$v_{4}$ & $1096 \mathrm{mw}$ & 1102 & 1092 & 314.1 & 7.2 & $55 \mathrm{~S}_{4}+45 \mathrm{~S}_{5}+18 \mathrm{~S}_{12}$ & $v\left(\mathrm{CF}_{3}\right)$ sym. \\
\hline$v_{5}$ & $751 \mathrm{~m}$ & 747 & 745 & 7.8 & 8.7 & $33 \mathrm{~S}_{5}+42 \mathrm{~S}_{4}+12 \mathrm{~S}_{12}$ & $\delta\left(\mathrm{CF}_{3}\right)$ sym. \\
\hline$v_{6}$ & $577 \mathrm{w}$ & 566 & 582 & 10.2 & 1.4 & $27 S_{7}+16 S_{9}+10 S_{2}$ & $\delta\left(\mathrm{CF}_{3}\right)$ antisym. \\
\hline$v_{7}$ & $551 \mathrm{w}$ & 541 & 550 & 4.7 & 1.0 & $55 \mathrm{~S}_{8}$ & $\delta\left(\mathrm{CF}_{3}\right)$ antisym \\
\hline$v_{8}$ & $489 \mathrm{~m}$ & 474 & 484 & 78.0 & 9.1 & $38 \mathrm{~S}_{6}+28 \mathrm{~S}_{7}+17 \mathrm{~S}_{10}$ & $v(\mathrm{~S}-\mathrm{Cl})$ \\
\hline$v_{9}$ & $461 \mathrm{w}$ & 450 & 467 & 35.9 & 2.8 & $17 S_{9}+22 S_{7}+18 S_{6}+15 S_{12}$ & wag. $(\mathrm{O}=\mathrm{S}-\mathrm{Cl})$ \\
\hline$v_{10}$ & $346^{*}$ vs & 332 & 348 & 5.8 & 9.3 & $34 \mathrm{~S}_{12}+18 \mathrm{~S}_{10}+16 \mathrm{~S}_{11}$ & $v(\mathrm{C}-\mathrm{S})$ \\
\hline$v_{11}$ & $301^{*} \mathrm{~s}$ & 288 & 303 & 3.9 & 7.7 & $35 \mathrm{~S}_{11}+32 \mathrm{~S}_{6}$ & $\rho\left(\mathrm{CF}_{3}\right)$ \\
\hline$v_{12}$ & $267^{*} \mathrm{~m}$ & 253 & 267 & 1.1 & 2.8 & $55 \mathrm{~S}_{10}+11 \mathrm{~S}_{12}+31 \mathrm{~S}_{13}$ & $\delta(\mathrm{O}=\mathrm{S}-\mathrm{Cl})$ \\
\hline$v_{13}$ & $211^{*} \mathrm{w}$ & 194 & 211 & 2.8 & 1.0 & $50 \mathrm{~S}_{13}+54 \mathrm{~S}_{9}+17 \mathrm{~S}_{11}+14 \mathrm{~S}_{14}$ & $\rho\left(\mathrm{CF}_{3}\right)$ \\
\hline$v_{14}$ & $163^{*} \mathrm{~m}$ & 146 & 151 & 0.7 & 1.7 & $64 \mathrm{~S}_{14}+21 \mathrm{~S}_{11}+17 \mathrm{~S}_{9}$ & twist. $(\mathrm{O}=\mathrm{S}-\mathrm{Cl})$ \\
\hline & - & 54 & 54 & 0.3 & 0.7 & $121 S_{15}+15 S_{13}+12 S_{11}$ & torsion $\left(\mathrm{CF}_{3}\right)$ \\
\hline \multicolumn{2}{|c|}{$\mathrm{RMSD}, \mathrm{cm}^{-1}$} & 18 & 11 & & & & \\
\hline
\end{tabular}

* Bands from Raman spectrum; ${ }^{a}$ B3LYP/6-311+G(3df) calculation; ${ }^{b}$ from scaled quantum mechanics force field (see text); ${ }^{c}$ infrared intensities in $\mathrm{Km} \mathrm{mol}^{-1}$; ${ }^{\mathrm{d}}$ Raman activities in $\AA^{4}(\mathrm{amu})^{-1}$; ${ }^{\mathrm{e}}$ contributions $\geq 10 \%$.

The $\mathrm{S}=\mathrm{O}$ polar bond can be described qualitatively by the mesomeric forms $\mathrm{FCF}_{3} \mathrm{~S}=\mathrm{O}$ and $\mathrm{FCF}_{3} \mathrm{~S}^{+}-\mathrm{O}^{-}$, as evidenced by the calculated and measured bond lengths (Table 1) which are considerably smaller than the single bond length of $1.67 \AA$ calculated with the Schomaker-Stevenson's formula. The values of the Wiberg indices indicate the intermediate state between these extreme mesomeric structures (see Table 9). 
Table 5. Natural internal coordinates for FS(O)Cl.

\begin{tabular}{ll}
\hline Definition (according to Fig. 1) & Description $^{\mathrm{a}}$ \\
\hline $\mathrm{S}_{1}=d(1-2)$ & $v(\mathrm{~S}=\mathrm{O})$ \\
$\mathrm{S}_{2}=l(1-4)$ & $v(\mathrm{~S}-\mathrm{F})$ \\
$\mathrm{S}_{3}=r(1-3)$ & $v(\mathrm{~S}-\mathrm{Cl})$ \\
$\mathrm{S}_{4}=\alpha(4-1-2)$ & $\delta(\mathrm{O}=\mathrm{S}-\mathrm{F})$ \\
$\mathrm{S}_{5}=\gamma(3-1-2)$ & $\delta(\mathrm{O}=\mathrm{S}-\mathrm{Cl})$ \\
$\mathrm{S}_{6}=\beta(3-1-4)$ & $\delta(\mathrm{F}-\mathrm{S}-\mathrm{Cl})$ \\
\hline
\end{tabular}

${ }^{a} v$, stretching; $\delta$, deformation.

Table 6. Natural internal coordinates for $\mathrm{CF}_{3} \mathrm{~S}(\mathrm{O}) X(X=\mathrm{F}$, $\mathrm{Cl})$.

\begin{tabular}{|c|c|}
\hline$\overline{\text { Definition (according to Fig. 1) }}$ & Description $^{\mathrm{a}}$ \\
\hline$\overline{\mathrm{S}_{1}=d(1-6)}$ & $v(\mathrm{~S}=\mathrm{O})$ \\
\hline $\mathrm{S}_{2}=2 p(2-3)-p(2-4)-p(2-5)$ & $v\left(\mathrm{CF}_{3}\right.$ antisym. $)$ \\
\hline $\mathrm{S}_{3}=p(2-4)-p(2-5)$ & $v\left(\mathrm{CF}_{3}\right.$ antisym. $)$ \\
\hline $\mathrm{S}_{4}=p(2-3)+p(2-4)+p(2-5)$ & $v\left(\mathrm{CF}_{3}\right.$ sym. $)$ \\
\hline $\begin{aligned} \mathrm{S}_{5}= & \psi(3-2-5)+\psi(3-2-4)+\psi(4-2-5) \\
& -\phi(3-2-1)-\phi(4-2-1)-\phi(5-2-1)\end{aligned}$ & $\delta\left(\mathrm{CF}_{3}\right.$ sym. $)$ \\
\hline $\mathrm{S}_{6}=l(1-7)$ & $v(\mathrm{~S}-X)$ \\
\hline $\mathrm{S}_{7}=2 \psi(4-2-5)-\psi(3-2-5)-\psi(3-2-4)$ & $\delta\left(\mathrm{CF}_{3}\right.$ antisym. $)$ \\
\hline $\mathrm{S}_{8}=\psi(3-2-5)-\psi(3-2-4)$ & $\delta\left(\mathrm{CF}_{3}\right.$ antisym. $)$ \\
\hline $\mathrm{S}_{9}=\beta(2-1-7)+\gamma(2-1-6)$ & wag. $(\mathrm{O}=\mathrm{S}-X)$ \\
\hline $\mathrm{S}_{10}=\alpha(6-1-7)$ & $\delta(\mathrm{O}=\mathrm{S}-X)$ \\
\hline $\mathrm{S}_{11}=\phi(4-2-1)-\phi(5-2-1)$ & $\rho\left(\mathrm{CF}_{3}\right)$ \\
\hline $\mathrm{S}_{12}=r(1-2)$ & $v(\mathrm{C}-\mathrm{S})$ \\
\hline $\mathrm{S}_{13}=2 \phi(3-2-1)-\phi(4-2-1)-\phi(5-2-1)$ & $\rho\left(\mathrm{CF}_{3}\right)$ \\
\hline $\mathrm{S}_{14}=\beta(2-1-7)-\gamma(2-1-6)$ & twist. $(\mathrm{O}=\mathrm{S}-X)$ \\
\hline $\mathrm{S}_{15}=\Sigma \tau\left[\mathrm{F}_{i}-\mathrm{C}_{2}-\mathrm{S}_{1}-\mathrm{O}_{6}, \mathrm{X}_{7}\right]$ & torsion $\left(\mathrm{CF}_{3}\right)$ \\
\hline
\end{tabular}

${ }^{a} v$, stretching; $\delta$, deformation; $\rho$, rocking.

The bond angles involving the $\mathrm{S}=\mathrm{O}$ bond are consistently larger than the corresponding $\mathrm{F}-\mathrm{S}-\mathrm{Cl}$ and $\mathrm{C}-\mathrm{S}-\mathrm{F}(\mathrm{Cl})$ angles, as predicted by the VSEPR theory [23], which postulates that double bonds should require more space in the coordination sphere of the central atom than single bonds (Fig. 1).

\section{Vibrational Spectra}

A revision of the published assignments for the title thionyl halides proposed by Kirchmeier and Shreeve [7] was undertaken by comparison between the experimental and calculated frequencies. The computed atomic displacement vectors for each vibrational mode served to understand the nature of the molecular vibrations.

\section{Assignments for $\mathrm{FS}(\mathrm{O}) \mathrm{Cl}$}

The reported bands at 435, 347 and $314 \mathrm{~cm}^{-1}$ can be better described as the $\mathrm{O}=\mathrm{S}-\mathrm{F}, \mathrm{O}=\mathrm{S}-\mathrm{Cl}$ and $\mathrm{F}-\mathrm{S}-\mathrm{Cl}$ deformation modes, respectively, in accordance with the corresponding calculated atomic displacements.
Table 7. Scaling factors for the force field of the $\mathrm{FS}(\mathrm{O}) \mathrm{Cl}$, $\mathrm{CF}_{3} \mathrm{~S}(\mathrm{O}) \mathrm{F}$ and $\mathrm{CF}_{3} \mathrm{~S}(\mathrm{O}) \mathrm{Cl}$ molecules.

\begin{tabular}{llll}
\hline Coordinates $^{\mathrm{a}}$ & $\mathrm{FS}(\mathrm{O}) \mathrm{Cl}$ & $\mathrm{CF}_{3} \mathrm{~S}(\mathrm{O}) \mathrm{F}$ & $\mathrm{CF}_{3} \mathrm{~S}(\mathrm{O}) \mathrm{Cl}$ \\
\hline$v(\mathrm{~S}=\mathrm{O})$ & 0.982 & 0.987 & 1.032 \\
$v(\mathrm{~S}-\mathrm{F})$ & 1.064 & 1.087 & - \\
$v(\mathrm{~S}-\mathrm{Cl})$ & 1.064 & - & 1.032 \\
$v(\mathrm{C}-\mathrm{S})$ & - & 1.140 & 1.141 \\
$v\left(\mathrm{CF}_{3}\right)$ & - & 1.026 & 0.925 \\
$\delta(\mathrm{O}=\mathrm{S}-\mathrm{F})$ & 1.064 & 1.026 & - \\
$\delta(\mathrm{O}=\mathrm{S}-\mathrm{Cl})$ & 1.371 & - & 1.032 \\
$\delta(\mathrm{F}-\mathrm{S}-\mathrm{Cl})$ & 1.371 & - & - \\
$\left.\delta(\mathrm{CF})_{3}\right)$ & - & 1.026 & 1.032 \\
$\left.\rho(\mathrm{CF})_{3}\right)$ & - & 1.140 & 1.228 \\
wag. $(\mathrm{O}=\mathrm{S}-\mathrm{F})$ & - & 1.026 & - \\
wag. $(\mathrm{O}=\mathrm{S}-\mathrm{Cl})$ & - & - & 1.141 \\
twist. $(\mathrm{O}=\mathrm{S}-\mathrm{F})$ & - & 1.140 & - \\
twist. $(\mathrm{O}=\mathrm{S}-\mathrm{Cl})$ & - & - & 1.032 \\
torsion $(\mathrm{CF}$ & & 1.000 & 1.000 \\
\hline a $v$, stretching; $\delta$, deformation; $\rho$, rocking. &
\end{tabular}

${ }^{\mathrm{a}} v$, stretching; $\delta$, deformation; $\rho$, rocking.

The potential energy distribution confirmed the proposed assignments (Table 2).

\section{Assignments for $\mathrm{CF}_{3} \mathrm{~S}(\mathrm{O}) \mathrm{F}$}

The frequencies and the atomic displacement vectors obtained in the calculations confirmed most of the reported band assignments for that molecule, with the exception of the bands located at 480, 342 and $289 \mathrm{~cm}^{-1}$. These bands are now assigned to the $\mathrm{O}=\mathrm{S}-\mathrm{F}$ wagging, to one of the $\mathrm{CF}_{3}$ rocking and to the $\mathrm{C}-\mathrm{S}$ stretching modes, respectively (Table 3 ).

\section{Assignments for $\mathrm{CF}_{3} \mathrm{~S}(\mathrm{O}) \mathrm{Cl}$}

The set of the vibrational frequencies measured by Kirchmeier and Shreeve [7] for this molecule are reproduced in Table 4, where the 461 and $346 \mathrm{~cm}^{-1}$ bands are assigned to the $\mathrm{O}=\mathrm{S}-\mathrm{Cl}$ wagging and to the $\mathrm{C}-\mathrm{S}$ stretching modes, respectively, inverting the previous assignment. The potential energy distribution justified these new assignments (Table 4).

The harmonic force fields in Cartesian coordinates generated by the GAUSSIAN programs for the three molecules were transformed to the set of coordinates defined in Tables 5 and 6 . The resulting force constants were subsequently scaled according to the methodology mentioned above.

The calculated scale factors corresponding to the main force constant associated with each coordinate are provided in Table 7, whereas the experimental and calculated frequencies, the predicted infrared and Raman intensities and the potential energy distributions for each molecule are listed in Tables 2, 3 and 4. The 
Table 8. Internal force constants for the molecules $\mathrm{FS}(\mathrm{O}) \mathrm{Cl}$, $\mathrm{CF}_{3} \mathrm{~S}(\mathrm{O}) \mathrm{F}$ and $\mathrm{CF}_{3} \mathrm{~S}(\mathrm{O}) \mathrm{Cl}$.

\begin{tabular}{|c|c|c|c|}
\hline$\overline{\text { Force constant }}{ }^{\mathrm{a}}$ & $\mathrm{FS}(\mathrm{O}) \mathrm{Cl}$ & $\mathrm{CF}_{3} \mathrm{~S}(\mathrm{O}) \mathrm{F}$ & $\mathrm{CF}_{3} \mathrm{~S}(\mathrm{O}) \mathrm{Cl}$ \\
\hline \multicolumn{4}{|l|}{ Bond stretches } \\
\hline$f(\mathrm{~S}=\mathrm{O})$ & 10.55 & 9.92 & 9.70 \\
\hline$f(\mathrm{~S}-\mathrm{F})$ & 3.74 & 3.90 & - \\
\hline$f(\mathrm{~S}-\mathrm{Cl})$ & 1.86 & - & 1.86 \\
\hline$f(\mathrm{C}-\mathrm{S})$ & - & 2.34 & 2.25 \\
\hline$f(\mathrm{C}-\mathrm{F})^{\mathrm{b}}$ & - & 6.37 & 5.75 \\
\hline$f(\mathrm{~S}=\mathrm{O} / \mathrm{S}-\mathrm{F})$ & 0.26 & 0.18 & - \\
\hline$f(\mathrm{~S}=\mathrm{O} / \mathrm{S}-\mathrm{Cl})$ & 0.33 & - & 0.21 \\
\hline$f(\mathrm{~S}=\mathrm{O} / \mathrm{C}-\mathrm{S})$ & - & 0.16 & 0.17 \\
\hline$f(\mathrm{C}-\mathrm{F} / \mathrm{C}-\mathrm{F})$ & - & 0.86 & 0.77 \\
\hline \multicolumn{4}{|l|}{ Deformations } \\
\hline$f(\mathrm{O}=\mathrm{S}-\mathrm{F})$ & 1.60 & 1.38 & - \\
\hline$f(\mathrm{O}=\mathrm{S}-\mathrm{Cl})$ & 1.74 & - & 1.18 \\
\hline$f(\mathrm{~F}-\mathrm{S}-\mathrm{Cl})$ & 1.70 & - & - \\
\hline$f(\mathrm{C}-\mathrm{S}=\mathrm{O})$ & - & 1.43 & 1.41 \\
\hline$f(\mathrm{~F}-\mathrm{C}-\mathrm{S})^{\mathrm{b}}$ & - & 0.84 & 0.92 \\
\hline$f(\mathrm{~F}-\mathrm{C}-\mathrm{F})^{\mathrm{b}}$ & - & 1.23 & 1.36 \\
\hline$f(\mathrm{O}=\mathrm{S}-\mathrm{F} / \mathrm{F}-\mathrm{S}-\mathrm{Cl})$ & 0.36 & - & - \\
\hline$f(\mathrm{O}=\mathrm{S}-\mathrm{F} / \mathrm{O}=\mathrm{S}-\mathrm{Cl})$ & 0.36 & - & - \\
\hline$f(\mathrm{O}=\mathrm{S}-\mathrm{F} / \mathrm{C}-\mathrm{S}-\mathrm{F})$ & - & 0.24 & - \\
\hline$f(\mathrm{O}=\mathrm{S}-\mathrm{Cl} / \mathrm{C}-\mathrm{S}-\mathrm{Cl})$ & - & - & 0.24 \\
\hline$f(\mathrm{O}=\mathrm{S}-\mathrm{F} / \mathrm{C}-\mathrm{S}=\mathrm{O})$ & - & 0.24 & - \\
\hline$f(\mathrm{O}=\mathrm{S}-\mathrm{Cl} / \mathrm{C}-\mathrm{S}=\mathrm{O})$ & - & - & 0.24 \\
\hline$f(\mathrm{C}-\mathrm{S}-\mathrm{F} / \mathrm{C}-\mathrm{S}=\mathrm{O})$ & - & 0.27 & - \\
\hline$f(\mathrm{C}-\mathrm{S}-\mathrm{Cl} / \mathrm{C}-\mathrm{S}=\mathrm{O})$ & - & - & 0.38 \\
\hline
\end{tabular}

a Units are mdyn $\AA^{-1}$ for stretches and stretch/stretch interactions and mdyn $\AA \mathrm{rad}^{-2}$ for angular deformations; ${ }^{\mathrm{b}}$ mean values.

SQM force fields were used to calculate the internal force constants compiled in Table 8.

\section{Discussion of the Results}

The most relevant experimental frequencies for the $\mathrm{FS}(\mathrm{O}) \mathrm{Cl}$ molecule and $\mathrm{SO}_{2}(X=\mathrm{F}, \mathrm{Cl}, \mathrm{Br})$ are collected in Table 9 along with the bond lengths, internal force constants and Wiberg indexes. The charges on the $\mathrm{S}$ atoms and the sum of the halogen electronegativities were also included in Table 9, and used to explain some trends with simple arguments. It can be seen that the values of these parameters reflect very well the changes in electronegativity and covalent radius of the halogen atoms. A higher positive charge on the $\mathrm{S}$ atom causes a displacement of electrons from the $\mathrm{O}$ atom, reinforcing the $\mathrm{S}=\mathrm{O}$ bond. The consequence is an increase of the $\mathrm{S}=\mathrm{O}$ bond order (as measured by the Wiberg index) and the corresponding frequencies and force constants, while the $\mathrm{S}=\mathrm{O}$ bond length decreases (Table 9). On the other hand, the $S-X$ distances show the expected increase on account of the increasing halogen covalent radius. A decrease of the stretching frequencies and force constants is therefore observed.
Table 9. Experimental frequencies and additional data for the $\mathrm{FS}(\mathrm{O}) \mathrm{Cl}$ and $\mathrm{SO}_{2}$ molecules $(X=\mathrm{F}, \mathrm{Cl}, \mathrm{Br})$.

\begin{tabular}{|c|c|c|c|c|}
\hline & $\mathrm{SOF}_{2}{ }^{\mathrm{a}}$ & $\mathrm{FS}(\mathrm{O}) \mathrm{Cl}$ & $\mathrm{SOCl}_{2}{ }^{\mathrm{a}}$ & $\mathrm{SOBr}_{2}{ }^{\mathrm{a}}$ \\
\hline$\overline{v(\mathrm{~S}=\mathrm{O}), \mathrm{cm}^{-1}}$ & 1330.4 & 1293 & 1261 & 1121 \\
\hline$d(\mathrm{~S}=\mathrm{O})$ (calcd. $), \AA$ & 1.422 & 1.429 & 1.438 & 1.444 \\
\hline$f(\mathrm{~S}=\mathrm{O}), \operatorname{mdyn} \AA^{-1}$ & 11.13 & 10.55 & 10.07 & 7.96 \\
\hline$W I(\mathrm{~S}=\mathrm{O})^{\mathrm{b}}$ & 1.566 & 1.522 & 1.454 & 1.421 \\
\hline Charge on the $\mathrm{S}$ atom ${ }^{\mathrm{c}}$, e & 1.838 & 1.574 & 1.271 & 1.138 \\
\hline$\Sigma \chi^{\mathrm{d}}$ & 8.0 & 7.0 & 6.0 & 5.6 \\
\hline$v(\mathrm{~S}-\mathrm{F}), \mathrm{cm}^{-1}$ & $\left\{\begin{array}{l}808.2 \\
747.0\end{array}\right.$ & 720 & - & - \\
\hline$d(\mathrm{~S}-\mathrm{F})$ (calcd.), $\AA$ & 1.610 & 1.617 & - & - \\
\hline$f(\mathrm{~S}-\mathrm{F})$, mdyn $\AA^{-1}$ & 4.06 & 3.74 & - & - \\
\hline$W I(\mathrm{~S}-\mathrm{F})^{\mathrm{b}}$ & 0.697 & 0.683 & - & - \\
\hline$v(\mathrm{~S}-\mathrm{Cl}), \mathrm{cm}^{-1}$ & - & 490 & $\left\{\begin{array}{l}500 \\
464\end{array}\right.$ & - \\
\hline$d(\mathrm{~S}-\mathrm{Cl})($ calcd. $), \AA$ & - & 2.107 & 2.113 & - \\
\hline$f(\mathrm{~S}-\mathrm{Cl}), \operatorname{mdyn} \AA^{-1}$ & - & 1.86 & 1.85 & - \\
\hline$W I(\mathrm{~S}-\mathrm{Cl})^{\mathrm{b}}$ & - & 0.852 & 0.848 & - \\
\hline
\end{tabular}

a Recalculated values using the B3LYP/6-311+G(3df) approximation, after ref. [5]; ${ }^{\mathrm{b}}$ Wiberg index [21] calculated with the NBO method [22]; ${ }^{\mathrm{c}}$ calculated with the NBO method [22]; ${ }^{\mathrm{d}}$ sum of the halogen electronegativities.

Table 10. Experimental frequencies and additional data for the $\mathrm{CF}_{3} \mathrm{~S}(\mathrm{O}) \mathrm{F}$ and $\mathrm{CF}_{3} \mathrm{~S}(\mathrm{O}) \mathrm{Cl}$ molecules.

\begin{tabular}{|c|c|c|}
\hline & $\mathrm{CF}_{3} \mathrm{~S}(\mathrm{O}) \mathrm{F}$ & $\mathrm{CF}_{3} \mathrm{~S}(\mathrm{O}) \mathrm{Cl}$ \\
\hline$\overline{v(\mathrm{~S}=\mathrm{O}), \mathrm{cm}^{-1}}$ & 1267 & 1242 \\
\hline$d(\mathrm{~S}=\mathrm{O})$ (calcd. $), \AA$ & 1.443 & 1.453 \\
\hline$f(\mathrm{~S}=\mathrm{O})$, mdyn $\AA^{-1}$ & 9.92 & 9.70 \\
\hline$W I(\mathrm{~S}=\mathrm{O})^{\mathrm{a}}$ & 1.470 & 1.397 \\
\hline Charge on the $\mathrm{S}$ atom ${ }^{\mathrm{b}}$, e & 1.492 & 1.203 \\
\hline$v(\mathrm{C}-\mathrm{S}), \mathrm{cm}^{-1}$ & 289 & 267 \\
\hline$d(\mathrm{C}-\mathrm{S})($ calcd. $), \AA$ & 1.910 & 1.919 \\
\hline$f(\mathrm{C}-\mathrm{S})$, mdyn $\AA^{-1}$ & 2.34 & 2.25 \\
\hline$W I(\mathrm{C}-\mathrm{S})^{\mathrm{a}}$ & 0.775 & 0.777 \\
\hline$v(\mathrm{~S}-\mathrm{F}), \mathrm{cm}^{-1}$ & 749 & - \\
\hline$d(\mathrm{~S}-\mathrm{F})$ (calcd.), $\AA$ & 1.627 & - \\
\hline$f(\mathrm{~S}-\mathrm{F})$, mdyn $\AA^{-1}$ & 3.90 & - \\
\hline$W I(\mathrm{~S}-\mathrm{F})^{\mathrm{a}}$ & 0.664 & - \\
\hline$v(\mathrm{~S}-\mathrm{Cl}), \mathrm{cm}^{-1}$ & - & 489 \\
\hline$d(\mathrm{~S}-\mathrm{Cl})$ (calcd. $), \AA$ & - & 2.107 \\
\hline$f(\mathrm{~S}-\mathrm{Cl}), \operatorname{mdyn} \AA^{-1}$ & - & 1.86 \\
\hline$W I(\mathrm{~S}-\mathrm{Cl})^{\mathrm{a}}$ & - & 0.825 \\
\hline
\end{tabular}

a Wiberg index [21] calculated with the NBO method [22]; ${ }^{\mathrm{b}}$ calculated with the NBO method [22].

The experimental frequencies and additional data for $\mathrm{CF}_{3} \mathrm{~S}(\mathrm{O}) \mathrm{F}$ and $\mathrm{CF}_{3} \mathrm{~S}(\mathrm{O}) \mathrm{Cl}$ are presented in Table 10. These values show clearly that, on passing from the $\mathrm{F}$ to the $\mathrm{Cl}$ compound, the decrease in substituent electronegativity causes an increase of the $\mathrm{S}=\mathrm{O}$ and $\mathrm{C}-\mathrm{S}$ distances, whereas the corresponding frequencies and force constants decrease, as expected. The Wiberg indexes for the $\mathrm{C}-\mathrm{S}$ bond, however, do not follow the same trend. The values for the $\mathrm{S}-\mathrm{F}$ and $\mathrm{S}-\mathrm{Cl}$ bonds are correlated by the variation of the covalent radius of the halogen atoms, as mentioned before. 


\section{Conclusions}

A DFT theoretical study was made on the structural and vibrational properties of the thionyl halides $\mathrm{FS}(\mathrm{O}) \mathrm{Cl}, \mathrm{CF}_{3} \mathrm{~S}(\mathrm{O}) \mathrm{F}$ and $\mathrm{CF}_{3} \mathrm{~S}(\mathrm{O}) \mathrm{Cl}$. It was found necessary to use the relatively large $6-311+\mathrm{G}(3 \mathrm{df})$ basis set to reproduce adequately the experimental geometrical parameters of $\mathrm{CF}_{3} \mathrm{~S}(\mathrm{O}) \mathrm{F}$ and the magnitude and order of the measured vibrational frequencies for the three molecules. The obtained bond lengths and force constants change along the set of molecules (which are also compared with the symmetric thionyl halides,
$\mathrm{SO}_{2}$ ) in accordance with the electronegativity and size of the substituents at the $\mathrm{S}=\mathrm{O}$ unit.

\section{Acknowledgement}

Research grants from the following institutions from the Republic of Argentina are gratefully acknowledged: CONICET (Consejo Nacional de Investigaciones Científicas y Técnicas), ANPCYT (Agencia Nacional de Promoción Científica y Tecnológica), UNLP (Universidad Nacional de La Plata) and CIUNT (Consejo de Investigaciones de la Universidad Nacional de Tucumán).
[1] L.E. Fernández, M. G. Verón, E. L. Varetti, Spectrochim. Acta 2004, 60A, 405-411.

[2] L. E. Fernández, E. L. Varetti, Spectrochim. Acta 2005, $62 A, 221-225$.

[3] L. E. Fernández, E. L. Varetti, J. Arg. Chem. Soc. 2009, 97, 199-209.

[4] L. E. Fernández, A. Ben Altabef, E. L. Varetti, J. Mol. Struct. 2002, 612, 1-11.

[5] L.E. Fernández, E. L. Varetti, Z. Naturforsch. 2007, $62 b, 1491-1496$.

[6] R. Minkwitz, W. Molsbeck, H. Oberhammer, I. Weiss, Inorg. Chem. 1992, 31, 2104-2107.

[7] R. L. Kirchmeier, J. M. Shreeve, Inorg. Chem. 1975, 14, $2431-2433$.

[8] D. Bielefeldt, G. Schatte, H. Willner, Inorg. Chem. 1988, 27, 2706-2709.

[9] M. E. Tucceri, M. P. Badenes, C. J. Cobos, J. Fluorine Chem. 2002, 116, 135-141.

[10] A. D. Becke, J. Chem. Phys. 1993, 98, 5648 - 5652.

[11] C. Lee, W. Yang, R. G. Parr, Phys. Rev. 1988, B37, 785 789.

[12] J. P. Perdew, K. Burke, Y. Wang, Phys. Rev. 1996, B54, $16533-16539$.

[13] C. Møller, M. S. Plesset, Phys. Rev. 1934, 46, 618 - 622.

[14] T. H. Dunning Jr., J. Chem. Phys. 1989, 90, $1007-$ 1023.

[15] M. J. Frisch, G. W. Trucks, H. B. Schlegel, G. E. Scuseria, M. A. Robb, J.R. Cheeseman, J. A. Montgomery, Jr., T. Vreven, K. N. Kudin, J. C. Burant, J. M. Millam, S. S. Iyengar, J. Tomasi, V. Barone, B. Mennucci, M. Cossi, G. Scalmani, N. Rega, G. A. Petersson, H. Nakatsuji, M. Hada, M. Ehara, K. Toyota, R. Fukuda, J. Hasegawa, M. Ishida, T. Nakajima, Y. Honda, O. Kitao, H. Nakai, M. Klene, X. Li, J.E. Knox,
H. P. Hratchian, J. B. Cross, C. Adamo, J. Jaramillo, R. Gomperts, R. E. Stratmann, O. Yazyev, A. J. Austin, R. Cammi, C. Pomelli, J. W. Ochterski, P. Y. Ayala, K. Morokuma, G. A. Voth, P. Salvador, J. J. Dannenberg, V.G. Zakrzewski, S. Dapprich, A.D. Daniels, M. C. Strain, O. Farkas, D. K. Malick, A. D. Rabuck, K. Raghavachari, J. B. Foresman, J. V. Ortiz, Q. Cui, A. G. Baboul, S. Clifford, J. Cioslowski, B. B. Stefanov, G. Liu, A. Liashenko, P. Piskorz, I. Komaromi, R. L. Martin, D. J. Fox, T. Keith, M. A. Al-Laham, C. Y. Peng, A. Nanayakkara, M. Challacombe, P. M. W. Gill, B. Johnson, W. Chen, M. W. Wong, C. Gonzalez, J. A. Pople, Gaussian 03, Gaussian, Inc., Pittsburgh, PA (USA) 2003

[16] G. Fogarasi, X. Zhou, P. W. Taylor, P. Pulay, J. Am. Chem. Soc. 1992, 114, $8191-8201$.

[17] E. B. Wilson, J. C. Decius, P. C. Cross, Molecular Vibrations, McGraw-Hill, New York, 1955.

[18] P. Pulay, G. Fogarasi, G. Pongor, J.E. Boggs, A. Vargha, J. Am. Chem. Soc. 1983 105, 7037-7047.

[19] W. B. Collier, FCARTP, Department of Chemistry, Oral Roberts University, Tulsa, OK (USA) 1992; QCPE \#631

[20] P. Ugliengo, D. Viterbo, G. Chiari, Z. Kristallogr. 1993, 207, 9-23.

[21] K. B. Wiberg, Tetrahedron 1968, 24, 1083 - 1096.

[22] A.E. Reed, L.A. Curtiss, F. Weinhold, Chem. Rev. 1988, 88, 899-926.

[23] a) R. J. Gillespie, Molecular Geometry, Van NostrandReinhold, London, 1972; b) R. J. Gillespie, I. Hargittai, The VSEPR Model of Molecular Geometry, Allyn and Bacon, Boston 1991; c) R. J. Gillespie, E. A. Robinson, Chem. Soc. Rev. 2005, 34, $396-407$. 